\title{
Caroline Waerzeggers. "Changing Marriage Practices in Babylonia from the Late Assyrian to the Persian Period"
}

\section{Reinhard Pirngruber}

\section{(2) OpenEdition \\ 1 Journals}

\section{Electronic version}

URL: https://journals.openedition.org/abstractairanica/51782

DOI: $10.4000 /$ abstractairanica. 51782

ISSN: 1961-960X

Publisher:

CNRS (UMR 7528 Mondes iraniens et indiens), Éditions de l'IFRI

\section{Electronic reference}

Reinhard Pirngruber, "Caroline Waerzeggers. "Changing Marriage Practices in Babylonia from the Late Assyrian to the Persian Period"'", Abstracta Iranica [Online], Volume 42-43 | 2021, document 11, Online since 30 December 2020, connection on 14 December 2022. URL: http://journals.openedition.org/ abstractairanica/51782 ; DOI: https://doi.org/10.4000/abstractairanica.51782

This text was automatically generated on 14 December 2022.

All rights reserved 
Caroline Waerzeggers. "Changing Marriage Practices in Babylonia from the Late Assyrian to the Persian Period"

Reinhard Pirngruber 


\section{REFERENCES}

Caroline Waerzeggers. "Changing Marriage Practices in Babylonia from the Late Assyrian to the Persian Period", Journal of Ancient Near Eastern History 7.2, 2020, p. 101-131

1 This article analyses the development of marriage practices in Babylonian according to marriage agreements and other legal records, in particular texts relating to the dowry, from the neo-Assyrian to the Achaemenid period. It can be shown that a clear bifurcation of society is in evidence, and the old-established urban elites, priestly families, did not mingle with socially inferior strata (comprising groups of different economic means: the urban poor, immigrants and deportees but also homines novi)

While until the early fifth century, this difference is also visible in the pertinent documentation, the pattern changes during or after the reign of Xerxes when a homogenizing trend becomes observable. Clauses that were formerly characteristic in marriage agreements of low-status couples disappear from the record, while the dowry became the most important aspects (as has already been the case in texts relating to elite marriages). For the author, this development is grounded amongst others in a levelling of social distinctions in Babylonia, which set in during the reign of Darius and culminated after the repression of the revolts against Xerxes in $484 \mathrm{CBE}$, when urban elites were decisively weakened.

\section{AUTHORS}

REINHARD PIRNGRUBER

Institut für Orientalistik, Wien 